This item was submitted to Loughborough's Research Repository by the author.

Items in Figshare are protected by copyright, with all rights reserved, unless otherwise indicated.

\title{
Is there a second life for librarians?
}

PLEASE CITE THE PUBLISHED VERSION

http://www.emeraldinsight.com/search.htm?st1=Probets\&ct=all\&ec=1\&bf=1

\section{PUBLISHER}

(C) Emerald

VERSION

AM (Accepted Manuscript)

\section{LICENCE}

CC BY-NC-ND 4.0

\section{REPOSITORY RECORD}

Elliot, Naomi, and Steve Probets. 2019. "Is There a Second Life for Librarians?". figshare. https://hdl.handle.net/2134/8608. 
This item was submitted to Loughborough's Institutional Repository (https://dspace.lboro.ac.uk/) by the author and is made available under the following Creative Commons Licence conditions.

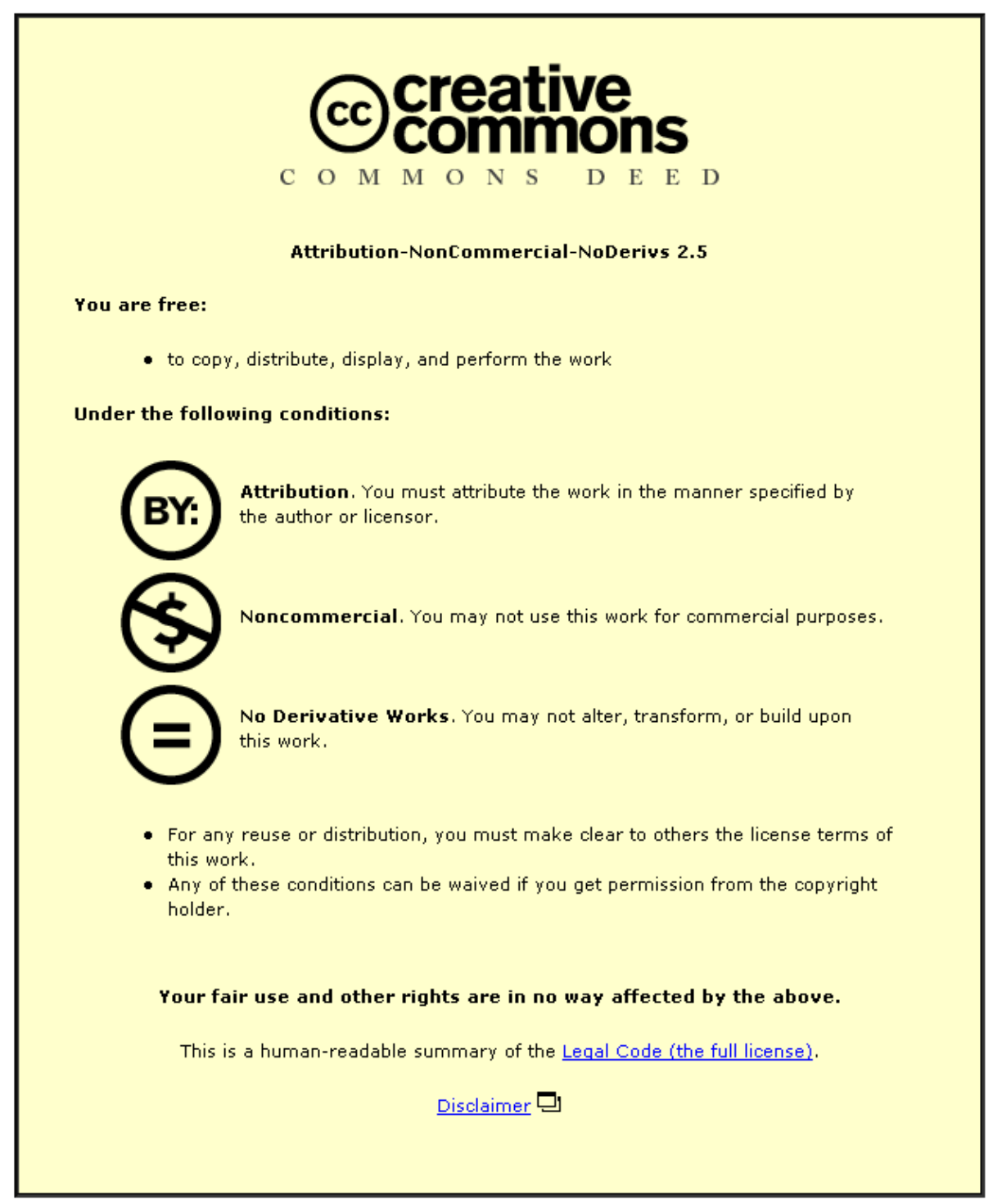

For the full text of this licence, please go to: http://creativecommons.org/licenses/by-nc-nd/2.5/ 


\section{Autobiographical note.}

\section{Authors: Naomi Elliott and Steve Probets}

Naomi Elliott: elliottn@citybathcoll.ac.uk

Main Library, City of Bath College, Avon Street, Bath, UK

Steve Probets: s.g.probets@lboro.ac.uk

Department of Information Science, Loughborough University, Loughborough, UK

\section{Professional Biographies:}

Naomi Elliott is a librarian for City of Bath College Library.

Steve Probets is a lecturer in the Information Science Department at Loughborough University. His research focuses on access to scholarly communication.

\section{Published version available at:}

http://www.emeraldinsight.com/journals.htm?issn=0264-0473\&volume=29\&issue=3 


\title{
Is there a Second Life for Librarians?
}

\author{
Naomi Elliott and Steve Probets
}

\section{Published version available at:}

http://www.emeraldinsight.com/journals.htm?issn=0264-0473\&volume=29\&issue=3

\begin{abstract}
Purpose - This paper explores the roles of libraries within Second Life from the viewpoint of the librarians experienced in experimenting within virtual worlds.

Design/methodology/approach - Exploration of currently available literature was undertaken to determine the important issues affecting libraries and librarians within virtual worlds. To explore these issues further, ten Second Life librarians were interviewed in order to distinguish which were most important and why.

Findings - There is considerable diversity in the opinions of Second Life librarians, but all interviewees shared the belief that their efforts within Second Life had helped others and improved their own professional development. There was a strong consensus that it was important for librarians to embrace Second Life now, in order to be prepared for a future when virtual worlds, although perhaps not Second Life itself, were commonplace.
\end{abstract}

Practical implications - Virtual worlds are growing in popularity, particularly with younger generations. If they are to be accepted as part of a multidimensional information space, the possibilities available within the virtual space need to be appreciated and understood by the information community. Librarians have a responsibility to aid their users in understanding the complexity and possibilities of information provision and delivery offered by virtual worlds. This can only occur by accepting and supporting experiments in environments like Second Life.

Originality/value - This paper illustrates to the library community how Second Life is currently being used to provide information services, and to further an understanding of how the entire information community can benefit from embracing the possibility of exploring virtual worlds.

Keywords -- Virtual Worlds, Second Life, Libraries, Librarians

Paper type - Research Paper 


\section{Introduction}

Second Life (SL) has divided opinion since its launch by Linden Lab in 2003 as "a free online virtual world imagined and created by its Residents" (Linden Lab, n.d.). In 2006 press coverage of SL reached extremely positive heights and big businesses seemed to be flocking into SL to open premises and invest their time and money. Business Week magazine (2006) devoted their front cover to a resident who had made \$1 million in SL, praising its economy and suggesting a ubiquitous future for virtual worlds like Second Life. However, alongside this hype there have always been more negative reactions to SL. Some of these have involved the criticism that comes with any technology perceived to encourage people to pursue virtual activities instead of more traditional real life past-times. Platform specific judgements have also been made, indicating that the learning curve was too steep and the purpose of SL too unclear to attract the critical number of users required to achieve mainstream adoption.

When several major businesses later withdrew from SL (Schofield, 2008), and it became clear that SL would never be able to reach the reported usage figures of the social network Facebook or the virtual world Habbo, this was taken by some as proof that SL had not, and would not, succeed. According to KZero, the virtual world consultancy research group, by late 2009 SL had 15 million accounts, significantly lower than the 158 million active users reported for Habbo (KZero, 2009) or the 400 million users registered with Facebook (n.d.).Despite this, SL saw over 481 million hours of usage in 2009 , so while user numbers may be low, the amount of time these users spend on SL is high. In addition, SL supports a significant and successful economy, which in 2009 saw $\$ 567 \mathrm{M}$ traded between users (Linden, 2010). SL is not the most popular application on the Internet, but this does not mean that there are not vast opportunities within it for people to explore, experiment or pursue their business and professional interests.

This variety of opinions about SL's use and potential was not simply limited to SL as a platform, but to the professions and individuals who choose to use it, including libraries. Libraries entered SL early in its development, often alongside educational institutions that were quick to embrace SL. According to Eduserv (2009) "nearly 
every UK University is using Second Life to some extent". The reason educational institutions and libraries focused their attentions on SL seems clear; unlike other, often more popular virtual worlds, like World of Warcraft or Habbo, which have dedicated objectives and set landscapes to achieve them in, SL allows users to create their own environment and choose their own activities. Because of this, it was the first, and remains the only, virtual world that can feasibly support the development of virtual educational institutions and libraries.

The much cited Gartner Group report (2007) stated that "80 percent of active Internet users will have a 'Second Life' in the virtual world by the end of 2011". This is undoubtedly part of the motivation to experiment within virtual worlds, as if this prediction materialises then virtual world usage will become the norm and all organisations whose users have an online presence will need to find a way of ensuring their services will be relevant in this future. The growth of virtual worlds would clearly bring major changes for libraries, and SL provides an opportunity for libraries to experiment in developing their services outside of the physical library. Much of this experimentation has taken place within the SL islands that make up the Info Archipelago, where the majority of libraries are based. Until 2010 the Info Archipelago was run by the Alliance Virtual Library, which was set up as a collaborative project funded by Alliance Library System to explore the potential for library services and resources within SL.

The much-publicised pull-outs of SL by major businesses including Reuters, Coca Cola and American Apparel (Hansen, 2009) caused questions to be raised about whether SL had failed, or if its appeal had ended. Similar questions could be asked about libraries' positions within SL, as late 2009 brought the announcement that the newly formed and non-profit Community Virtual Library would be taking over from the Alliance Virtual Library in administrating all the information islands (ALA, 2009). This was due to the withdrawal from SL of the Alliance Library System (ALS), the real-life company who had been the major funder and supporter of SL libraries since their conception. What the future holds for libraries in SL is unclear but with this change in administration and reliance on fund raising to meet costs, the position of libraries within SL appears precarious. SL has confused several commentators, and no doubt some users as well, because it does not fit comfortably into traditional definitions of virtual worlds, computer games, or chat programmes and so it is unclear what to 
expect from it or what to do within it. SL undoubtedly contains elements of them all, but lacks many others, such as a designated objective that most games seek to achieve. This is what gives SL the potential to be home to a vast range of user groups, from gamers, to being used as a social network, or business location, or somewhere to develop new forms of information provision. It means that regardless of the success of SL as a platform, both financially and in terms of usage, simply using and experimenting within SL can have a much wider application than could be achieved in other virtual worlds.

\section{Aims}

Commercial companies' withdrawals from SL have raised questions about the viability of Second Life as both a commercial and popular venture, and whether libraries can survive or be sustainable within SL is part of this debate. Assessing the achievements, and the motivations behind them, is more vital than ever when considering whether virtual libraries, whether based within SL or within other virtual environments, could ever have the potential to be widely used by, or even replace, physical libraries in the real world.

The primary aim of this research was to provide an overview of the current activities and attitudes of librarians within SL, and to investigate whether there was a sustainable role within SL for them. To this end, the objectives that this study aimed to address were to discover what librarians are doing in SL, to identify what they believe their purpose in SL to be, and to ascertain what opportunities SL offers libraries and librarians, both positive and negative.

As the research methods used in this study were conducted within SL, a second aim was to consider the suitability of SL for conducting research and to make recommendations to other researchers considering $S L$ as a research tool. While this latter aim is deemed out of scope for this paper, some of the issues associated with conducting research in SL are outlined in the Methodology section below.

\section{Background: Libraries and Second Life}


Previous research and articles about library participation within SL has raised a number of interesting issues that primarily tackle questions such as why libraries are in SL and what librarians are doing there. Grassian and Trueman (2007, pp.84-89) suggest that two common reasons to explain why librarians are keen to experiment in SL are to reach users, and to benefit their professional development. Within the literature there has been a trend to list not only common purposes like these, but also to attempt to identify the full range of activities open to a librarian within SL. For example, Hurst-Wahl's (2007) exhaustive list of activities SL librarians undertake included providing library services to residents, networking, and positioning for the future. Hedreen, et al. (2008, pp.167-195) made the same suggestions but separated them into the broader library service areas of reference, instruction and collections. And Parker (2008b, p.237) suggested even more activities, such as offering tours and linking to digital collections, which further expanded the already extensive list of activities librarians carry out in SL.

Within the literature, much of it taken from the authors own experiences augmented by the views of other librarians, there is clear reluctance to identify any one activity as more important, or more widely undertaken, than any other. This is understandable as librarians are not sure how SL will evolve and identifying certain activities as more important than others could limit their roles unnecessarily. As Bell (2009, cited in Burnett, 2009) was quoted as saying, "[SL is] a whole new way to teach and learn; the possibilities are endless". While great educational opportunities do not automatically equate to great opportunities for libraries, it is this vast range of possibilities that SL presents to libraries that is its greatest benefit, and offers an explanation as to why the literature about librarians' SL activities can appear vague.

Concerns about why SL should be of any importance to libraries and librarians have also been raised. Peek (2007, pp.15-16) asked whether anyone is really using SL libraries, how they will make money and what happens about staffing? Ideological concerns like these about the nature of SL and the impact it could have on real world libraries are not the only issues relating to libraries in SL that must be addressed if they are to succeed. Advocates of SL libraries are not ignorant of SL's limitations as a platform, and are often the loudest critics of its technical restrictions. For example, Bell, Pope and Peters (2008, pp.26-29) discussed some of the challenges librarians can face within SL, building on those previously discussed in Bell et al. (2007, pp.14- 
18). They discuss SL's lack of reliability, the limitation of the search engine, limits on how many users can be in one place, and issues over integrating the Internet and other media into SL. Parker (2008a, pp.13-14) also referred to technical limitations, and went on to outline that the steep learning curve required to make effective use of $\mathrm{SL}$ is a serious drawback to it achieving mainstream adoption. Even this brief background shows that the impact of SL on libraries and librarians is far from clearly understood and that further analysis of the views of librarians who inhabit SL can help to shed light on the role that SL can play for libraries and librarians.

\section{Methodology}

The literature described above shows more than the context within which this research project is set; it indicates areas that require further investigation. While some of these points cannot be resolved by a single project, through semi-structured interviews the viewpoints of librarians who have experimented with SL can be captured and expressed.

It was felt that allowing the interviewees to describe their activities in, and opinions of, $S L$ in their own words, whilst guided by predetermined themes, was the best way to gain an insight into the way librarians experienced and understood SL. It was also decided that conducting these interviews in-world was the only feasible way of contacting interviewees who were purposively selected based on their experience of librarianship in both the real and virtual worlds and thus located over a widespread geographical area. SL interviews do not encounter problems regarding the dispersed locations of interviewees and travel costs. While telephone or email interviews could also have overcome these geographical barriers to some extent, they would have presented some of the disadvantages outlined by Bryman (2004, pp.477-478) as they do not allow the interviewer to capitalise upon body language, and rapport is harder to establish. As SL more closely mimics face-to-face interviews and even gives inhabitants the opportunity to make any physical gestures they deem appropriate, the impact of these disadvantages is reduced.

Conducting interviews in-world was also advantageous because it overcame one of the major barriers facing qualitative researchers - transcription. By using text-based 
chat within SL, transcription occurs automatically, and this traditional interview barrier is avoided. In addition, SL can be considered the interviewees 'natural environment', and interviewing within it did not interrupt their normal flow of events, thereby allowing the researcher to be better placed in understanding the social reality of the situation (Bryman 2004, p.339).

Initial contact with potential interviewees was made through in-world instant messaging. This was useful for making initial contact with potential interviewees as messages could be left when users were off-line, but it allowed only short amounts of information to be shared. In order to ensure interviewees understood the topics the interview would cover, an interview guide was designed and shared with them. Although this meant responses to questions were less spontaneous than in face-toface interviews, it allowed the interviewees to give more considered responses. The interview guide originally comprised of nine clearly defined sections based on issues derived from a thorough literature review. The questions were intended to allow respondents to place emphasis on issues that were significant to them, and were designed to be open enough to allow interviewees' insights and opinions on SL to emerge. After piloting the interview with two SL librarians it became clear that inworld interviews could be extremely time-consuming mainly due to the typing requirements and so the number of sections was cut to seven.

It was vital that the sample selected for interview would produce information-rich responses based on considerable experience in SL. The lack of sufficient information about the SL librarian populations made it difficult to sample on the basis of probability as there was no accessible sampling frame that could be used, therefore a snowball sampling approach was followed (Bryman 2004, p.102). Snowball sampling was possible because SL's librarian population is focused around one main area, and networking is widespread. Therefore it seemed likely that those most experienced within SL would know each other, and be well-placed to suggest good interview subjects. Before snowball sampling could occur, initial subjects for interviews were identified by purposive sampling. The assumption was made that those identified as 'directors' and 'managers' of the SL group 'Librarians of SL', would be prominent and active in SL. Five of these individuals were contacted for interviews, and asked to recommend additional participants. 
The size and composition of the sample was not pre-determined because the study aimed to get quality in-depth answers, and it could not be predicted how many interviews it would take to collect this. The decision was made to conduct at least eight detailed interviews to provide some breadth to the answers, and then review the collected data to see if more interviews were required to add further information.

Out of twenty librarians contacted in the summer of 2009, seventeen people responded to the initial interview request, although five of these did not subsequently reply to later communications to arrange interview details. Due to technical reasons two of the remaining twelve could not be interviewed meaning that ten in-depth interviews were conducted in total.

Following the completion of the interviews, themes were drawn from the responses using thematic grids. This involved working through each transcript and transferring the information into the grid, creating new theme columns as they were identified. This approach is not something that can be done easily or quickly, but provides a very thorough understanding of the subject and the way people feel about it (Moore 2006, p.156).

Brief anonymised descriptions of the ten interviewees are provided in Table 1.These details were correct for summer 2009 when the interviews were conducted, and significantly at a time before AVL had pulled out of SL. Librarians $E$ and $G$ have library related roles in both SL and the real world but did not wish for further details to be disclosed.

Table 1 - Background information of interviewees

\begin{tabular}{|lll|}
\hline & SL job & Real world job \\
\hline Librarian A & Info Island reference manager & $\begin{array}{l}\text { Senior librarian at a US Public } \\
\text { Library }\end{array}$ \\
& & \\
\hline Librarian B & Works for a book discussion & Children's Services Specialist at \\
& group & a US public library \\
\hline Librarian C & Director of Caledon Libraries & Curator at US University \\
& {$[1]$, set within a Victorian- } & \\
\hline
\end{tabular}




\begin{tabular}{|lll|}
\hline \multicolumn{3}{|c|}{ themed community } \\
\hline Librarian D & $\begin{array}{l}\text { Runs Olathe public library, and } \\
\text { volunteers for AVL }\end{array}$ & Librarian at a US public library \\
\hline Librarian E & $\begin{array}{l}\text { Runs SL extension of real-life } \\
\text { Library and works for AVL }\end{array}$ & US Librarian \\
& & \\
\hline Librarian F & Trains customers about SL, & Library Services Manager for \\
& Previously ran SL Library & commercial company \\
& & UK Librarian \\
& Former AVL reference desk & \\
\hline Librarian G & Volunteer & Library Assistant, UK public \\
& lesk & \\
\hline Librarian I & $\begin{array}{l}\text { Director of Alliance Virtual } \\
\text { Library }\end{array}$ & Director of Innovation at the \\
& & Alliance Library System \\
\hline Librarian J & $\begin{array}{l}\text { Director of Library Resources } \\
\text { and Services for AVL }\end{array}$ & Reference Librarian at US \\
& & University \\
\hline
\end{tabular}

\section{Interview Findings}

\section{Activities undertaken by SL librarians}

Despite the fact that authors like Hurst-Wahl (2007) and Parker (2008b) between them have produced a list of over twenty activities undertaken by librarians within $\mathrm{SL}$, providing reference services was the only activity mentioned by every interviewee as a SL librarian activity. This suggests that the range of activities librarians can do within SL remains unknown, as is the extent to which they are carried out. However, from the frequency with which it is referred to, it is not unfair to suggest reference services, often focusing on providing help in navigating within SL, or answering enquiries on wider topics of interest, are the most commonly occurring task for SL librarians. 
Related to the provision of reference services, all interviewees felt librarians could not be selective over what information they provided, and that they should aim to meet the information needs of the community that they serve, whether physical or virtual. One librarian described this as "what we do, what all libraries do, is make available to a community the materials for the conversation they are already having". That answering enquiries translates so easily from real life into SL, and provides quantifiable methods of ensuring users are reached, may explain why this was a focus for the interviewees and for prior research. However, whether reference services are what SL users really require from libraries, or if, as one librarian suggested, librarians are doing it "by default" as it is the easiest typical librarian role to do in SL, was not clear and needs to be investigated further.

Several interviewees suggested that although tasks like providing reference services could and should be replicated, other aspects of physical libraries should not. A typical response was the claim that "we can do much to promote reading and information here, but not providing the materials themselves". Two interviewees suggested that SL was not somewhere to replicate real world library services that were already better offered elsewhere, while another did not think replicating services would be particularly useful due to SL's small population. This suggests that SL libraries have to offer services that are either different, or superior, to those available in real life, or reach a different section of users in order to be of value.

Two interviewees suggested that comparing real world and SL libraries could be detrimental to the development of SL libraries. One librarian suggested that becoming hung up on the word "library" could prevent users' information needs being met. Similarly, another librarian suggested that focusing on how librarianship within SL related to real life would give librarians a distorted view of SL because it is intended to be somewhere to experiment with completely new designs, ideas and ways of interacting, not to be a location in which to simply replicate the real world. By focusing on how librarianship in SL relates to real life libraries, and whether what occurs there meets the definition of libraries and librarianship, librarians risk failing to make use of its full potential.

Qualities for SL librarians 
The qualities and skills required of a SL librarian is not a topic pursued within the literature, perhaps because there is an assumption that they do not differ from those required in the real world. The interviews sought to investigate this topic directly. While there was consensus among the interviewees that the same values and skills, which made a good librarian in real life were still required in SL, there were also additional skills needed in order to succeed, particularly the need for good technology skills, proficiency in SL, being adaptable to change, able to experiment and three suggestions that a sense of humour is essential. However, a typical response of all the interviewees was the suggestion that "good librarianship is consistent between SL and [real life]".

\section{Awareness of libraries}

Currently most libraries within SL are located in close proximity to each other on the group of islands that make up the Info Archipelago. There was a significant difference of opinion among the interviewees as to whether this was a benefit. Although five librarians expressed the view that "users and librarians ... can wander from one specialist site to another" and so allow easy collaboration, other interviewees felt that locating the library islands together ran too high a risk of users never finding and using any of them. Three interviewees suggested that the purpose of having a presence in SL was to be "where the users are", but if the users do not know you are there, then there seems to be little point in this. If the purpose of libraries in SL is to serve SL's current users then they need to be in locations where they can be found. Despite the fact that all interviewees acknowledged the need to promote libraries outside the Info Archipelago in order to attract users, the current location of most libraries within the Info Archipelago suggests that the needs of librarians, and their desire to be close to other library professionals, may be being placed before the needs of users.

One librarian explicitly stated that "I think that libraries should actively be trying to reach SL users - otherwise why be here?". Despite agreement among interviewees on the need to improve library visibility within SL, no clear path was suggested as to how this could be achieved. The two main suggestions were to ensure libraries appeared in the SL search engine, and to collaborate with both other libraries and wider organisations. The former suggestion was made by five interviewees, which is 
surprisingly frequent given the major problems with the SL search engine, which Bell, Pope and Peters (2007) described as having "major drawbacks". In 2007 Linden Lab CTO Cory Ondrejka promised that it was "time to make search in Second Life really work," (Terdiman, 2007) but despite subsequent changes, the search engine continues to attract criticism. These are largely due to the lack of clarity on how exactly rankings are determined (Linden Lab, 2008) and the inclusion of traffic figures[2]. The flaws in the SL search engine, which can rank classified ads and locations which have unfairly inflated their traffic figures above others, mean that inworld advertising is not currently a good way of attempting to raise the profile of libraries within SL.

Interviewees had further suggestions for promoting SL libraries, including holding inworld events, ensuring SL libraries appear within Internet search engines and inworld advertising through posters and notecards. These approaches seem to have a higher chance of success than focusing resources on SL's search engine. However, a more fundamental problem facing libraries than finding a way to promote them was suggested by two of the interviews. One librarian described that "there is no culture of libraries in SL", because users do not grow up with libraries in SL as they do in real life it may never occur to them to search for one.

Some interviewees also remarked on the fact that even though SL technology limits locations to 40 users at one time, libraries do not have enough members of staff available to deal with even this few users at once. These limitations mean that even if users' default mindset can be overcome through raising SL libraries visibility and ensuring users know they exist, there are still technological and administrative barriers in place that would have to be overcome to ensure the smooth functioning of SL libraries.

\section{Advantages and limitations of librarians using $S L$}

When discussing the advantages and limitations of librarians being in SL, the interviewees mainly covered professional development, particularly networking, experimentation and preparing for the future.

The general feeling among interviewees was that SL provides access to fellow professionals on a worldwide scale, and allows conversations that are richer, and 
more dynamic than those that can take place on social networks like Facebook. Within SL, librarians can engage in in-depth meaningful conversations on any topic, as well as visiting or creating a place they are talking about, or sharing resources. Every interviewee mentioned networking as an extremely important aspect of SL, and a major part of why SL is a great professional development tool.

Another topic of importance to interviewees, and one that is largely overlooked in the literature, is that every action SL librarians make can be considered an experiment in offering information access in a virtual environment. In particular, libraries within SL experiment with different ways of offering virtual reference services, creating immersive learning environments, and with designing library buildings. The interviewees were in agreement that librarians should be expected to experiment, and that doing so was the only way to discover what services virtual worlds can provide to users. One librarian explained that "a library has to change with the times, so innovation is part of the library's remit". The benefits to be gained from experimenting within SL were widely remarked upon, with three interviewees comparing the ease with which SL allowed experimentation, to the problems of doing so with the physical library. There was also agreement over a point described by one librarian that "even if [virtual worlds] don't take off, SL still helps librarians as professionals". The idea that librarians can benefit from simply using SL regardless of success, was described by one librarian as "Learning ... it's a lot about learning to fail". While only one other interviewee also suggested the ability to fail was a benefit of $\mathrm{SL}$, it is this aspect of experimentation that can easily attract criticism of SL. Critics who try to find a use for SL, and fail to do so, have questioned whether it is worth funding. It seems unlikely that the suggestion that SL allows librarians to learn by failing will persuade doubters of SL's worth and value, yet it is through being in precisely that environment, which fosters experimentation, that innovative and ground-breaking developments emerge.

The most frequently mentioned restriction to using SL was obtaining funding. Interviewees suggested that a main part of the reason it is difficult to get funding appears to be because of SL's user-base. One librarian explained how their library administrator had expressed "concern... that the project does not directly benefit "our" patrons". This is supported by another librarian's statement that it is "hard to get funding for programmes that go beyond the area of the real world library". The 
suggestion of authors like Herring (2007, p.59) that, instead of using SL, libraries should "concentrate on real services to real patrons" is probably representative of this attitude that "real" patrons are those you serve physically. For critics like these, experimentation sounds too much like a vague aim, with the distinct possibility of producing no success or tangible results and so SL is not seen as something that provides enough benefits to the library profession to receive funding.

That there is no guarantee of success within SL and no guidelines to follow, just possibilities to be explored, is why one librarian suggested that "people who can't think out of the box can't survive in here", and that librarians within SL should "have something unique to bring to the table". While other interviewees were not as forthright in their opinions, these points really only echo the views expressed by all interviewees when discussing the qualities required of SL librarians; that if a librarian is not highly adaptable and comfortable using technology, they will contribute little to experimentation within SL

While most interviewees saw SL as having immense long-term prospects, many also stated that they did believe libraries needed to embrace it for it to remain relevant in the short-term. If SL is a technology that librarians must accept in order to be able to serve a future generation of library users, then the librarians within it need to have a long-term vision and accept that their efforts might not produce discernible success for years. SL certainly seems to be a likely area of future interest for libraries as virtual worlds are rapidly growing in popularity, with nearly 60 percent of the $579,000,000$ estimated registered accounts across all virtual worlds belonging to users aged between 10 and 15 (KZero, 2009). If virtual world usage is maintained, or grows as this younger generation matures, then, as one librarian suggested, libraries need to be prepared to meet the needs of this user-base and provide the resources they want and need, and to do this librarians need to be familiar with the virtual worlds their users are using. However, it is important to remember that although virtual worlds seem to be growing in popularity, this does not mean that SL is also growing. There are hundreds of worlds in existence and two of the librarians interviewed made it clear that although they believed virtual worlds would be highly relevant in future, they did not necessarily think SL would be. 
The fact that librarians are using SL to develop services for a possibly far distant situation, which might involve an entirely different virtual world, will always attract opposition from those who prefer to concentrate on the short-term and what they already know works. The problem with this mindset is that without experimentation it will never be known if there was something that might have worked far better. Four of the interviews suggested that using SL lessened the risk of libraries ceasing to be relevant in the future. As one librarian stated, by using SL "instead of waiting to react, we are there with the innovators". Librarians are not using SL because they believe that $S L$ is the future for libraries, but because virtual worlds might be, and SL currently offers the best way for librarians to experiment and discover their potential.

\section{Conclusions and recommendations}

The following recommendations and conclusions can be drawn about the state of libraries in SL and the issues that are most important for librarians.

\section{Activities}

Although a wide range of activities are undertaken by librarians within $\mathrm{SL}$, the International Reference Desk is the one aspect of library service within SL that was constantly referred to within the interviews. It was presented as somewhere that, through the collaborative efforts of librarians, successfully provides a live library service that the general SL population used.

\section{Location, visibility and cooperation}

In order to know if their services work effectively or not, SL users must actually use them, and interviewees agreed that in order to attract these users libraries must ensure they are as well known in SL as possible. Utilising the SL search engine, hosting events to interest users and encouraging word of mouth promotion, are all techniques librarians have found to be successful. However, largely because they are providing library services for an interest-based virtual community instead of geographically defined real world communities, libraries receive little, if any, funding for SL and so the extent to which this sort of promotion can be done is currently limited. 
An alternative and cost-effective form of promotion is cooperation, which allows libraries to share resources, staffing requirements, costs and experience.

Cooperation not only increases library visibility but also improves the quality of library service offered. Equally, cooperating with non-library organisations within SL will increase libraries appeal to communities who would not use libraries otherwise. One example of cooperation is the Stonewall Learning Centre, which is a feature on the Community Library System's Info Island, and is used to host the Stonewall discussion series which non-library groups, such as the Transgender Research Center, have participated in. Cooperation has the added benefit of showing the wider library profession a way in which SL can be used to create attractive partnerships with other groups and companies regardless of their geographical location.

The concentration of libraries on the Info Archipelago, while beneficial to librarians who can collaborate with ease, was also felt by the interviewees to negatively affect both the questions received from users and the visibility of the library. If most SL users do not know libraries exist then there is no reason for libraries to offer services within SL. So, while difficult to do, raising awareness of libraries throughout all of SL and the wider world is essential.

\section{Professional development}

All the interviewees indicated professional development to be a major advantage for librarians using SL, in some cases this was the only definite short-term benefit that could be identified. There was agreement between the interviewees about the fact they should experiment, and what they hoped to achieve by doing it, but not over what it should involve. There were differing opinions about precisely which services a library should offer, how a virtual library should be designed, or the best way to increase library visibility. The fact that it is not clear what works and what does not, is the reason why further experimentation is needed.

Experimentation by librarians within SL is vital to the success of SL libraries and must be embraced if they are to succeed. However, it is important to remember that this is not an environment for those who cannot see past the image of libraries as books and bricks. SL requires librarians who are adaptable, who more often than not must invest their own time and money in SL, who are prepared to possibly 
experience failure in their experimentation, and who are able to deal with negative reactions to their work from critics of SL. SL has much to offer librarians in terms of both personal and professional development, but only to those who have something to offer in return.

\section{The future and wider adoption}

Technological limitations still restrict mainstream adoption of SL, and the platform may never overcome this. Not all libraries can afford to take this risk in terms of both time and money. So, for the foreseeable future it seems likely that SL will remain the preserve of those libraries that believe SL can help them develop better library services and reach new users in the long-term, and those librarians with the dedication and vision to do this. However, it would seem that the wider library profession still has a role to play in supporting libraries in SL. It is important that those who are attempting to develop library services within SL are given some room to experiment and are not unduly restricted by the very profession they are trying to benefit. It would be detrimental to development within SL if people became too hung up on defining libraries and librarians within SL. Virtual worlds allow new areas to be explored and blur previously established boundaries, allowing roles to merge and overlap. So long as access to information services is provided, then it is not essential that the person doing so calls themselves a librarian or that the building is a library.

Even if Second Life is consigned to the footnotes of history without ever providing a suitable location for libraries, then other virtual worlds will still continue to thrive and the lessons learnt in Second Life will provide librarians with the best possible platform to succeed in them. Libraries will need to adapt their services to succeed in new eras of technology and much of what SL librarians are doing now will ensure they are well-placed to successfully guide the way.

\section{Notes}

1 - Caledon is a Victorian-themed community with numerous lands within SL. There are eight libraries, which develop collections focusing on the 19th century, and Caledon's defining literary genres, Steampunk and Alternate History.

2 - Using traffic figures to determine placing in the search rankings has proved controversial as bots and camping ( where additional accounts are created and 
payment is offered to others to stay in particular buildings or regions for extended periods of time) can heavily distort rankings

\section{Bibliography}

ALA, (2009), "Facebook group note - Community Virtual Library to take over from AVL in Jan 2010", available at: http://www.facebook.com/note.php?note id=155124076207 (accessed 04.02.10).

Bell, L, Pope, K. \& Peters, T. (2008), "The universal library in a virtual universe: second life and second chance for librarians?", Searcher, 16 (5), pp. 26-29, available at:

http://www.library.idsc.gov.eg/GUI/Globals/Upload//BULLETIN ATTACHMENT/99/efiles/libraries\%20and\%20information\%20science/the\%20universal\%20library.pdf (accessed 29.06.09).

Bell, L. et al. (2007), "Who's on third in Second Life?: from library 2.0 to library 3.0", Online, 31 (4), p. 14-18, available at:

http://www.accessmylibrary.com/coms2/summary 0286-32574243 ITM (accessed 29.06.09).

Bryman, A. (2004), Social research methods, $2^{\text {nd }}$ ed., Oxford University Press, Oxford.

Burnett, E. (2009), "Virtual libraries in SL", available at:

http://www.slentre.com/virtual-libraries-in-sl-\%E2\%80\%9Cpatrons-not-only-readabout-characters-in-a-novel-they-have-an-opportunity-to-interact-withthem\%E2\%80\%9D/ (accessed 26.06.09).

Business Week, (2006), "My virtual life", available at:

http://www.businessweek.com/magazine/content/06 18/b3982001.htm?chan=search (accessed 28.12.09).

Eduserv, (2009), "The Spring 2009 Snapshot of Virtual World Use in UK Higher and Further Education", available at: http://www.scribd.com/doc/12459921/The-Spring2009-Snapshot-of-Virtual-World-Use-in-UK-Higher-and-Further-Education (accessed 20.02.09).

Facebook, (n.d), "Press Room - Statistics", available at:

http://www.facebook.com/press/info.php?statistics (accessed 05.03.10).

Gartner Group, (2007), "Gartner says 80 percent of active internet users will have a "second life" in the virtual world by the end of 2011", available at:

http://www.gartner.com/it/page.jsp?id=503861 (accessed 01.02.09). 
Grassian, E. \& Trueman, R.B. (2007), "Stumbling, bumbling, teleporting and flying ... librarian avatars in Second Life". Reference Services Review, [Online]. 35 (1), pp. 84-89, available at:

http://www.emeraldinsight.com/Insight/viewPDF.jsp?contentType=Article\&Filename= html/Output/Published/EmeraldFullTextArticle/Pdf/2400350106.pdf (accessed 05.02.09).

Hansen, L. (2009), "What happened to Second Life?", available at: http://news.bbc.co.uk/1/hi/8367957.stm (accessed 17.01.10).

Hedreen, R. C., et al. (2008), "Exploring virtual librarianship: Second Life Library 2.0", Internet Reference Services Quarterly, 13 (2-3), pp. 167-195, available at: http://dx.doi.org/10.1080/10875300802103833 (accessed 29.04.09).

Herring, M.Y. (2007), "Get a (real) life!", Library Journal, available at: http://www.libraryjournal.com/article/CA6440565.html (accessed 05.02.09).

Hurst-Wahl, J. (2007), "Librarians and Second Life: it's a source of information, a platform for networking, an opportunity to try out new approaches before you take them to the real world", Information Outlook, 11 (6), available at: http://findarticles.com/p/articles/mi m0FWE/is 6 11/ai n19311772/pg 1 (accessed 05.02.09).

KZero research. (2009), "Universe", available at: http://www.kzero.co.uk/blog/?page id=2537(accessed 22.07.09).

Linden Lab. (n.d.), "What is Second Life?", available at: http://secondlife.com/whatis/ (accessed 03.02.09).

Linden Lab. (2008), "Tips to improve your search ranking", available at: https://blogs.secondlife.com/community/features/blog/2008/03/26/tips-to-improveyour-search-ranking (accessed 08.02.10).

Linden T. (2010), "2009 end of year Second Life economy wrap up (including q4 economy in detail)", available at:

https://blogs.secondlife.com/community/features/blog/2010/01/19/2009-end-of-yearsecond-life-economy-wrap-up-including-q4-economy-in-detail (accessed 08.02.10).

Moore, N. (2006), How to do research: a practical guide to designing and managing research projects, $3^{\text {rd }}$ rev. ed, Facet, London.

Parker, L. (2008a), "More questions than answers: the reflections of Maggie Kohime, a virtual librarian in Second Life", Aliss Quarterly, 3 (2), pp.13-17, available at: http://eprints.whiterose.ac.uk/3624/ (accessed 05.02.09).

Parker, L. (2008b), "Second Life: the seventh face of the library?", Program: Electronic Library and Information Systems, 42 (3), pp.232-242, available at: http://www.emeraldinsight.com/Insight/viewPDF.jsp?contentType=Article\&Filename= html/Output/Published/EmeraldFullTextArticle/Pdf/2800420302.pdf (accessed 14.06.09). 
Peek, R. (2007), "Librarians on Second Life", Information Today, 24 (2), pp.15-16, available at: http://goliath.ecnext.com/coms2/gi 0199-6253282/Librarians-onSecond-Life-Focus.html (accessed 05.02.09).

Schofield, J. (2008), "Reuters quits Second Life", available at: http://www.guardian.co.uk/technology/blog/2008/nov/23/reuters-quits-secondlife (accessed 08.02.10).

Terdiman, D. (2007), "Rescuing search in "Second Life"', available at: http://news.cnet.com/Rescuing-search-in-Second-Life/2100-1043 3-6161697.html (accessed 08.02.10). 